\title{
Corporate Social Responsibility and Contemporary Community Expectations
}

\author{
Bingyan $\mathrm{Li}^{1} \&$ Chunyao Wang ${ }^{1}$ \\ ${ }^{1}$ Business School, Monash University, Melbourne, Australia \\ Correspondence: Bingyan Li, 2/59 Margot St, Chadstone, Melbourne, VIC, 3148, Australia. Tel: \\ 61-45-162-0329.
}

Received: October 24, 2019

Accepted: November 14, 2019

Online Published: December 14, 2019

doi:10.20849/abr.v4i3.688

URL: https://doi.org/10.20849/abr.v4i3.688

\begin{abstract}
This report evaluates the effectiveness of corporate social responsibility and contemporary community expectations. It analyses the definition of corporate social responsibility and the community expectations of CSR. The findings indicate that some company corporate social responsibility policy meet the community expectations. For instance, Westpac bank acts well in gender equality and scholar and Telstra has good performance in charity. However, there remain conflicts between CSR and community expectations. Optus collects customer information and leakage with careless conflicting legal element. Clean Tech provides the environmental service which is opposite of economic element in CSR. This report proposes some recommendations for company to keep balance for both CSR and community expectations.
\end{abstract}

Keywords: corporate social responsibility, community expectations, comparison

\section{Introduction}

In the contemporary society, the economic prosperity was created in many countries through the economic integration. Millions of companies were established and developed rapidly in recent years. However, many companies only focus on improve their interest ignoring the world environmental costs. Some companies exploit the natural resources without limitation and even do not provide a safe work environment for the workers (Baker and Nofsinger, 2012). Governments should take their responsibility to protect people who work and live in the country from extreme working condition and living environment. Based on this situation, there must be some method to prompt company to aim at long term and sustainable development, which generally protect the environment and society. The traditional view of Australian companies is acting in the best interest of shareholders, creditors and the companies that would be the barrier to sustainable development (Sjåfjell et al., 2015). This article focuses on corporate social responsibility should be reckon in the company responsibility. In this article, the following aspects will be discussed: the definition of corporate social responsibility, community expectation to corporate, the similarity and different between CSR and expectations. Finally, the conclusion will be provided after deep research of CSR and expectations following the recommendation for improving the situation.

\section{Corporate Social Responsibility}

The Corporate Social Responsibility is an important measurement to evaluation the companies' competitive strength, survival and economic performance (Runhaar \& Lafferty, 2008). CSR is regard as a standard of judgment for deciding to protect a cleaner environment and a better society, which could be an effective method to monitor the company's behaviours. As Carroll's statement (2008, as cited in Ubreziova et al., 2017), the majority of companies are devoted to executing corporate social responsibility into their business strategy. The Carroll's CSR pyramid theory is the most recognized principle describing the notion of CSR, which is popular in developed countries (Sheehy, 2014). There are four levels in CSR theory including economic, legal, ethical and philanthropic. The first level of these functions is economic, which is located at the bottom of the pyramid. Economics in this theory means that companies have the obligation to gain profit (Deigh, Farquhar, Palazzo \& Siano, 2016). Profit taking is the most fundamental priority point that companies usually focus on. Second, the legal responsibility requires business to achieve profit under obeying the legal provisions. Apart from economic expectations, there are established minimal ground rules including regulations, laws and ethical behaviors in CSR theory (Turker, 2008). The economic element and legal element are the basis of the concept fir contract of 
society forming the demand expectations of the society. In addition to these two, the ethical function is the third level of CSR theory expecting companies to perform more ethical. It is not codified by law and only be expected by society. The government requires companies to involve the environmental protection target, such as reducing carbon emissions, into their development planning, which is an effective measurement to reduce greenhouse effect and achieve business requirements in society (Hussein, 2010). The philanthropic element, the fourth elements, is the discretionary in nature ranked at the peak of pyramid. To apply this element, enterprises should take their responsibility of building the quality and better life for the citizens in society. Enterprises usually take different approaches reach this standard. For instance, the enterprise may make effort in community development, donations and volunteering (Sheehy, 2014).

Above all, corporate social responsibility requirements are beyond the companies' financial benefits which is related to the community (Deign, Farquhar \& Siano, 2016; Aguinis \& Glavas, 2017; Seivwright \& Unsworth, 2016). Nowadays, CSR plays an important role in running a business all over the world. It is essential for an enterprise to reach a high level of CSR, such as contribution in a sustainable environment, human right and improvement of life's quality in local community. The achievement of CSR can satisfy the needs of community leading to good reputation and benefits (Ubreziova et al., 2017). In long term development, the successful companies would pursue the higher level of CSR, ethical and philanthropic functions, when they accomplish the basic functions.

\section{Community Expectation}

Contemporary community expectation is related to what enterprises can benefit them and how can the enterprises provide better conditions for community (Johnston, 2012). For example, people may look to companies fund or help them do what they want to do, provide better service with a lower price and protect the environment while running the business. The factors which influence communities' opinions about corporate social responsibility depend on past experience, familiarity with companies and the likelihood of companies may satisfy their needs. Besides, community expectation may also influence by other factors. For instance, how can the community expectations be expressed to particular enterprise? What is the consequence when the enterprise fails to fulfill a promise of CSR and how to examine the failure or success?

The social responsibility of corporations becomes the significant popular topic in contemporary, because of companies' considerable power and influence (Corporations and Markets Advisory Committee, 2006). According to communities' opinion, the companies use the society's resources to conduct their business so that companies should take responsibility for the consequence of their actions and they are expected to contribute in the issued that communities are concerned. Although governments can push corporate to meet community's expectations by legislative or regulatory initiatives, there are some limitations existed. Legislation can only set the standard to limit the extent that company should take the social responsibility, but government cannot legislate the law to enforce company to do a particular thing under CSR. Each company has their own characteristic so every company has to generate their strategy which fit their own conditions. Moreover, the enterprise should be subject to evaluation and criticism, which can ensure that the whole expectations of investors, employees, customers, especially the local communities will be considered in companies' plan. Furthermore, government is expected to monitor companies implement of CSR with the clear division of duty. The specific agencies which are responsible could provide better information about expenditure and achievements increasing the accountability.

\section{Comparison of CSR and Community Expectation}

In Australia company, community expectations of CSR are shown in their CSR policy in the context of the gender equality, scholarship projects and charity system. By contrast, there are two aspects, including public information safety and environmental service, to show the conflicts between community expectations of CSR and profitability.

\subsection{Similarities Between CSR and Community Expectation}

\subsubsection{Gender Equality}

Gender equality is a highly concerned issue in recent years especially in developed regions. Each community expects to have the same rights and obligation when they working in a company. Female expects that they can get the promotion opportunities as male employee. Male expects that they could have fair right of vocation, for instance, paternity leave. There are detailed planning and active behavior for reducing and eliminating gender discrimination in Australia. Westpac Banking Corporation, an Australian major banking organizations and financial service provider, is the oldest bank to be established in Australia. It also has great reputation because of 
the sustainability strategies including CSR policies. Westpac Bank describe "it is simply about having a set of decent values and behaviors that underpin our everyday activities" (Westpac, 2012). Gender equality also is an important policy in Westpac, in which a series of measures are executed. For instance, paid parental leave which has been provided by Westpac since 1995. Westpac not only provide it to female employees but also provide paid partner leave to male employees ("Gender equality | Westpac", 2017). In addition, the proportion of gender of leadership roles is half and half. Despite there are not $50 \%$ female in their board of directors and members of executive team, their work of gender equality is still recognized by specialized public organization and their own employees. On the one hand, the talents who concern about equality of opportunity and feminism are attracted. Therefore, Westpac benefited from this in the talent market. On the other hand, the most intuitive impact is that the equality of values is one of universal values which helps corporation to obtain better reputation in the market. "Bank reputation positively impacts economic performance" (Dell'Atti, Trotta, Lannuzzi \& Demaria, 2017). Thus, the impact will reflect on bank profitability.

\subsubsection{Scholars}

There are many big enterprises, which utilize the most resources in the world. Therefore, they have more responsibility to help people in the same world. Generally, people expect companies to use a part of profit in helping community. Westpac keeps higher concern on CSR either before or after the sub-prime crisis. The Bicentennial foundation claims they have donated \$12.6 million for supporting education and technological innovation. In addition, Westpac committed that they will provide $\$ 100$ million and 100 scholarships a year in the long term. Donation is the primary CSR strategy and most direct form of philanthropy. Westpac has other motivations behind philanthropy which is reason why Westpac concerns about Australia-Asia aspect. Asia has the most essential commercial connection with Australian corporations. Westpac identifies one of its stakeholders, Asian customers, for gaining competitive advantage. The advantage not only profitability in target market but also the vantage points in human resource. So positive interaction with people who come from Westpac's main target market can increase the favorability. Deigh et al. (2016) evaluated that strengthening the quality of human resources and physical infrastructure is the reason why companies should support education institutions, scholars and students who have high education. Nevertheless, achieving the purpose requires long-term effort. Meanwhile, committing to CSR behavior of supporting education and technology can boost the company's goodwill (Schwartz \& Carroll, 2003).

\subsubsection{Charity}

As the article mentioned before, community expect big company take their responsibility to help people who are in bad environment. If the company is capable, it is expected to help people to solve significant problems in the world. Philanthropic responsibility has been communicated by Telstra effectively in promoting employees' participation in community programs. Telstra, founded in 1975, is Australia's leading telecommunications and technology company offering a full array of telecom services such as mobile services and broadband services (Telstra, n. d.). As a consequence, Telstra has made an enormous contribution to the community through funds and partnerships. For example, Telstra donated over $\$ 1.5$ million to Asian tsunami relief aid funds in 2006 and provided around $\$ 250,000$ of services including establishing call centers, providing extra phone lines, fund-raising campaigns and volunteer support (Telstra, 2006). According to Telstra's Sustainability report (2017) Telstra kids has accumulated grants of over $\$ 9.8$ million to 8000 projects which benefits kids in the local community ever since 2002. The report also shows that the total contribution of Telstra's community investment programs is $\$ 157.4$ million in FY17. Nevertheless, it was noticeable that the annual investment by Telstra's Fund has decreased by near $\$ 60$ million during the past three years (Sustainability report, 2017). This implies that the employees' poor engagement in fund raising could be a fundamental reason behind it as the company's employees are the main contributors to the donations.

\subsection{Conflict Between CSR and Company's Profit}

\subsubsection{Public Information Safety}

SingTel Optus Pty Limited, founded in 1981 as AUSSAT, is the second largest telecommunications company in Australia. Under the laws of Australia, the Optus managers have formulated a series of policies that legitimately obtain customer information and protect their personal data. According to Optus's SingTel Annual Report (2016), the data privacy policies include various types of information they collect legally: quality of personal information, how to access customers' information, why collect personal information, credit related information, advertisement and security. Generally, Optus collects customer information, including name, gender, address, occupation, date of birth, contact details and credit situation, for providing more suitable products and services to customers. In addition, Optus is forced to accept certain personal information by Australia law. For example, 
crime rates can be reduced to protect the lives and property of citizens by filtering different kinds of information to prevent criminal activities. However, Optus still should spend money to establish more facilities for protecting customers information and data transaction in the supply chain. Recently, the Consulate - General Of The people's Republic China In Melbourne (2018) notices that an increasing number of Chinese citizens have received fraudulent calls from fraudsters who said they are couriers or police men. These fraudsters steal customer private information through their telecommunication data to get more money, and make people to believe that they are real official staffs. Therefore, the Consulate - General Of The People's Republic China In Melbourne issued a notice reminding citizens not to trust these calls easily to prevent telephone fraud. Above all, a telecommunication company, which want to meet contemporary community expectation, should hire more technical personnel and establish a system to help their customers filtering out these phishing calls.

\subsubsection{CleanTech and Environmental Services}

The contemporary community expectation of CSR in this part requires company reducing environmental issues and encouraging development of renewable energy. Westpac commits to provide $\$ 6$ billion lending to the CleanTech and environmental services. Companies committing to sustainable conduct could strengthens bank reputations (Dell'Atti et al., 2017). This collaboration with renewable energy companies to create more business opportunities through combining ethics with commercial strategy. Moreover, financial services and products are homogenous, Jain et al. (2015) argued that CSR activities are regard as an opportunity to differentiating their products. Deigh et al. (2016) believed that this kind of investment not only help banks to gain more market share, but also optimize the processes and services in the unbanked. However, Oxfam (2014) exposed that Westpac and WTK, a logging company in Papua New Guinea (PNG), have a banking relationship. According to investigation by PNG's Department of National Planning and Monitoring, almost $\$ 5$ million hectares of land were used to log by WTK in fact, on the pretext of agricultural development. Despite Westpac did not directly participate the activity, the financial cooperative relationship is contrary to the original vision of the policy. Dell'Atti et al. (2017) mentioned that the relationship between environmental factor and reputation depends on the importance which concerned by stakeholders. In other word, without negative impact to reputation in local market, profit-driven decision could easily be made, because environmental issues have not been taken seriously enough in PNG. For avoiding directly or indirectly participant the unsustainable projects, Westpac should improve their work on investigating overseas partners and oversighting partner corporations' behaviors. It is important to a firm making an ethical decision when their social and economic goals are inherently conflicting.

\section{Conclusions and Recommendations}

This report uses the theory of CSR through companies' sustainable policy and performance to analyse whether CSR meets contemporary community expectations or not. Some companies, like Westpac and Telstra, achieve social requirements in scholarship and charity because of improving project and experience. By contrast, Optus and Westpac should spend more money in operating activities and balance the conflicts between profit and community expectations. Additionally, government and Australia Securities and Investments Commission should provide more clear and strict revaluation standards to ensure whether the companies' CSR policy meet contemporary community expectations. These recommendations will help companies fulfil their CSR policies more effectively and achieve contemporary community expectations for the sake of improving the companies' reputation and customer loyalty.

\section{References}

Baker, H. K., \& Nofsinger, J. R. (2012). Socially responsible finance and investing: An overview. Socially responsible finance and investing: Financial institutions, corporations, investors, and activists, 1-14.

Chris, J. (2012). What are the community expectations for heritage protection. [online] Environment.gov.au. $\begin{array}{llll}\text { Retrieved } & 13 & \text { Sep. } & \text { 2018, }\end{array}$ http://environment.gov.au/system/files/pages/f4d5ba7d-e4eb-4ced-9c0e-104471634fbb/files/essay-expectati ons-johnston.pdf

Corporations and Markets Advisory Committee. (2006). The social responsibility of corporations. Sydney.

Deigh, L., Farquhar, J., Palazzo, M., \& Siano, A. (2016). Corporate social responsibility: engaging the community. Qualitative Market Research: An International Journal, 19(2), 225-240.

Dell'Atti, S., Trotta, A., Iannuzzi, A., \& Demaria, F. (2017). Corporate Social Responsibility Engagement as a Determinant of Bank Reputation: An Empirical Analysis. Corporate Social Responsibility and Environmental Management, 24(6), 589-605. https://doi.org/10.1002/csr.1430

Du Plessis, J. (2017). Corporate Social Responsibility and Contemporary Community Expectations. 
Gender equality | Westpac. (2017). Westpac.com.au. Retrieved from https://www.westpac.com.au/about-westpac/inclusion-and-diversity/Inclusion-means-everyone-matters/gen der-equality/

Jain, A., Keneley, M., \& Thomson, D. (2015). Voluntary CSR disclosure works! Evidence from Asia-Pacific banks. Social Responsibility Journal, 11(1), 2-18. https://doi.org/10.1108/srj-10-2012-0136

Melbourne.china-consulate.org. (2018). The foreign ministry's Consular Department reminding overseas Chinese citizens to guard against counterfeit Chinese telecommunications fraud in the name of the embassies and consulates abroad. from http://melbourne.china-consulate.org/chn/consulate_news/t1525306.html

Optus. $\quad$ (2016). SingTel Annul $\quad$ Report. $\quad$ Retrieved https://media.optus.com.au/wp-content/uploads/2016/06/Singtel-Annual-Report-2016.pdf

Optus. (2016). Sustainable $\quad$ Report. $\quad$ Retrieved from https://www.optus.com.au/content/dam/optus/documents/about-us/sustainability/Sustainability-Report-2016 .pdf

Oxfam. (2014). Banking on Shaky Ground. Oxfam Australia.

Runhaar, H., \& Lafferty, H. (2008). Governing Corporate Social Responsibility: An Assessment of the Contribution of the UN Global Compact to CSR Strategies in the Telecommunications Industry. Journal of Business Ethics, 84(4), 479-495.

Schwartz, M., \& Carroll, A. (2003). Corporate social responsibility: a three-domain approach. Business Ethics Quarterly, 34(2), 503-530. https://doi.org/10.5840/beq200313435

Sheehy, B. (2014). Defining CSR: Problems and Solutions. Journal of Business Ethics, 131(3), 625-648.

Sjåfjell, B., Johnston, A., Anker-Sørensen, L., \& Millon, D. (2015). Shareholder primacy: the main barrier to sustainable companies.

Telstra. (2006). Corporate Social Responsibility. Retrieved from https://www.telstra.https://www.telstra.com.au/content/dam/tcom/aboutus/investors/pdf\%2com.au/content/d am/tcom/aboutus/investors/pdf\%20C/corpsocial.pdf

Telstra. (n. d.). Bigger Picture 2017 Sustainability Report. Retrieved from https://1u0b5867gsn1ez16a1p2vcj1-wpengine.netdna-ssl.com/wp-content/uploads/2017/10/Bigger-Picture2017-Sustainability-Report.pdf

Ubreziova, I., Kurcova, R., \& Horvathova, J. (2017). How can ewe see the corporate social responsibility within its application in business practice, Acta Universitatis Agriculturae et Silviculturae Mendelianae Brunensis, 65(38), 339-346.

Westpac. (2012). Corporate Responsibility and our business (p.10). Westpac Banking Corporation. Retrieved from http://www.westpac.com.au/docs/pdf/aw/Corporate_Responsibility03.pdf

\section{Copyrights}

Copyright for this article is retained by the author(s), with first publication rights granted to the journal.

This is an open-access article distributed under the terms and conditions of the Creative Commons Attribution license (http://creativecommons.org/licenses/by/4.0/). 